\title{
Inferior dislocated patella locked by a loose body
}

\author{
Yunhao Qin, Jiong Mei
}

Department of Orthopedics, Shanghai Sixth People's Hospital, Shanghai, China

\section{Correspondence to}

Dr Yunhao Qin:

yunhao_qin@163.com

Accepted 25 January 2021

\section{DESCRIPTION}

Inferior patellar dislocation is rare in clinical practices. ${ }^{1}$ A 57 -year-old man presented to the emergency department after slipping while cleaning the floor in the knee sitting position. He reported he suddenly slipped forward during the initiation of standing. Trauma evaluation revealed no intracranial, intrathoracic or intrabdominal injuries. He kept the left knee in flexion and had severe pain while extension. Lateral radiographs and CT scans of the left knee showed the patellar was locked by a loose body (figure 1). He underwent the peripheral nerve block of the lower left limb. The patellar was unlocked by being pushed to the distal end while slowly extending the knee. The post-reduction radiographs revealed the left patellar restored to normal position (figure 2). The patient accepted a knee brace for temporary fixation and was recommended further surgical intervention. ${ }^{2}$ However, the patient decided not to take the surgery and then was asked for a regular follow-up. Currently, the patient has returned to daily life.
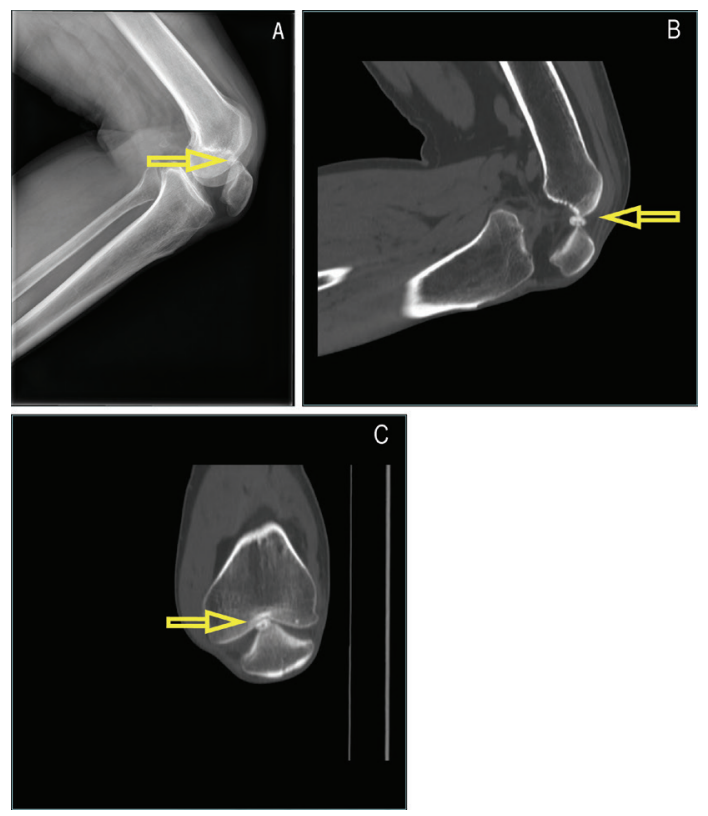

Figure 1 (A) Lateral radiograph of the left knee, (B) lateral CT scan of the left knee and (C) axial CT scan of the left knee. All figures demonstrated an inferior dislocated patella locked by a loose body (yellow arrows).
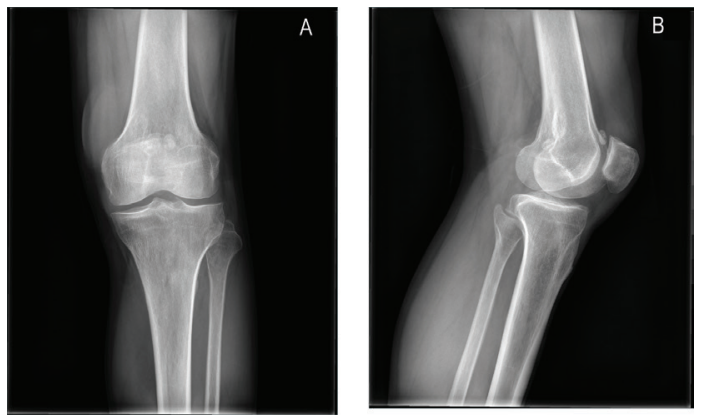

Figure 2 (A) Anteroposterior radiograph of the left knee and (B) lateral radiograph of the left knee. Both figures demonstrated the patellar restored to normal position after manual reduction.

\section{Learning points}

- Inferior patellar dislocation affects patients with osteoarthritis and osteophytes.

- Peripheral nerve block and manual reduction are appropriate therapy for an inferior dislocated patellar.

The origination of loose body remains controversial. Common causes of knee loose bodies are injuries to cartilage, osteoarthritis and inflammatory. In this case, the patient was a retired worker and was diagnosed with osteoarthritis 10 years ago. $\mathrm{He}$ reported no locking or catching of his knee in the past 10 years.

Contributors YQ provided the image. YQ and JM revised the manuscript. YQ wrote the manuscript and treated the patient.

Funding This case report was supported by the National Natural Science Foundation of China (8190090238, to YQ).

Competing interests None declared.

Patient consent for publication Obtained.

Provenance and peer review Not commissioned; externally peer reviewed.

\section{REFERENCES}

1 Yoshioka S, Arai Y, Ikoma K, et al. Two cases of inferior dislocation of the patella with impaction into the femoral trochlea of osteophytes on the superior pole of the patella. Case Rep Orthop 2013:2013:1-4.

2 Barlow D, Foong KS, Rhee SJ, et al. Recurrent locked knee caused by an impaction fracture following inferior patellar dislocation: a case report. J Med Case Rep 2011;5:347. 
Images in...

Copyright 2021 BMJ Publishing Group. All rights reserved. For permission to reuse any of this content visit https://www.bmj.com/company/products-services/rights-and-licensing/permissions/

BMJ Case Report Fellows may re-use this article for personal use and teaching without any further permission.

Become a Fellow of BMJ Case Reports today and you can:

- Submit as many cases as you like

- Enjoy fast sympathetic peer review and rapid publication of accepted articles

Access all the published articles

Re-use any of the published material for personal use and teaching without further permission

Customer Service

If you have any further queries about your subscription, please contact our customer services team on +44 (0) 2071111105 or via email at support@bmj.com.

Visit casereports.bmj.com for more articles like this and to become a Fellow 